\title{
Erratum to: Coastal and interior Douglas-fir provenances differ in growth performance and response to drought episodes at adult age
}

\author{
Anne-Sophie Sergent • Nathalie Bréda • \\ Leopoldo Sanchez • Jean-Charles Bastien • \\ Philippe Rozenberg
}

Published online: 13 August 2014

(C) INRA and Springer-Verlag France 2014

\section{Erratum to: Annals of Forest Science}

DOI 10.1007/s13595-014-0393-1

While processing the article two mistakes have been introduced in the names of two of the authors: Léopoldo Sanchez should have been spelled Leopoldo Sanchez. Jean-Charles Bastein should have been spelled Jean-Charles Bastien. Everything else in the article remains correct.

The online version of the original article can be found at http:// dx.doi.org/10.1007/s13595-014-0393-1.

A.-S. Sergent $\cdot$ L. Sanchez $\cdot$ J.-C. Bastien $\cdot$ P. Rozenberg INRA, UR 588 Amélioration, Génétique et Physiologie Forestières, 2163 Avenue de la Pomme de Pin, CS 40001 Ardon, 45075 Orléans Cedex 2, France

N. Bréda $(\bowtie)$

INRA, UMR 1137 Ecologie et Ecophysiologie Forestières, Route de la Forêt d'Amance, 54280 Champenoux, France

e-mail: breda@nancy.inra.fr

\section{N. Bréda}

Université de Lorraine, UMR 1137 Ecologie et Ecophysiologie

Forestières, BP 239, 54506 Vandoeuvre, France 